\title{
Invading Freshwater Snails and Biological Control in Martinique Island, French West Indies
}

\author{
Jean-Pierre Pointier \\ Laboratoire de Biologie Marine et Malacologie, EPHE, UMR 5555 du CNRS, Université de Perpignan, \\ 52 Avenue de Villeneuve, 66860 Perpignan, France
}

Eight alien freshwater snail species were introduced into Martinique Island during the last 50 years. The introduced snails include four planorbids (Biomphalaria straminea, Helisoma duryi, Amerianna carinata and Gyraulus $s p$.), three thiarids (Melanoides tuberculata, M. amabilis and Tarebia granifera) and one ampullarid (Marisa cornuarietis). Four of these species rapidly colonized the whole Martinican hydrographic system whereas the other four remained restricted to some particular sites. The invasion processes were documented during the last 20 years and showed (i) a rapid invasion of the island by several morphs of M. tuberculata at the beginning of the 80's; (ii) the introduction of T. granifera in 1991 and M. amabilis in 1997; and (iii) the rapid spread of these last two species throughout the island. In the years following its introduction, M. tuberculata was used in biological control experiments against the snail hosts of schistosomiasis, B. glabrata and B. straminea. Experiments were conducted with success in several groups of water-cress beds which constituted the latest transmission sites for schistosomiasis at the beginning of the 80's. A malacological survey carried out in 2000 all over the island showed the absence of B. glabrata but the presence of some residual populations of B. straminea. Long-term studies carried out in Martinique have shown that the thiarids are able to maintain relatively stable populations over a long period of time, thus preventing recolonization by the snail hosts. Within this context the invasion of the hydrographic system of Martinique by thiarid snails has resulted in an efficient and sustainable control of the intermediate hosts of schistosomiasis.

Key words: invading snails - biological control - Melanoides tuberculata - Melanoides amabilis - Tarebia granifera - Biomphalaria glabrata - Biomphalaria straminea - Martinique

Biological invasions have received special attention for many years because numerous invasive species may become serious pests (Williamson 1996). In this respect, the case of invading molluscs has been studied for a long time because of their economic damage and disturbance (Mead 1979), their impact on endemic faunas (Civeyrel \& Simberloff 1996), or their role in the transmission of parasites to humans (Malek 1980). However, recent studies carried out on freshwater snails in the Neotropical area have shown that invading species may have a positive influence from the human health point of view, some of them displacing others which are responsible for the transmission of serious para-

This work received financial support from the Service Parasitoses de la DDASS, Martinique and the French Ministère de l'Aménagement du Territoire et de l'Environnement, Programme Ecosystèmes Tropicaux. Fax: +33-4-6850.3686. E-mail: pointier@univ-perp.fr Received 14 May 2001

Accepted 25 July 2001 sitic diseases (Prentice 1983, Pointier et al. 1991, Pointier 1999). The case of Martinique Island is especially relevant to this situation because several biological control programmes of Biomphalaria glabrata (Say, 1818) and B. straminea (Dunker, 1848) snail intermediate hosts of schistosomiasis have been conducted in the 80's using a competitor snail, the thiarid Melanoides tuberculata (Müller, 1774) soon after its accidental introduction into this island (Pointier et al. 1989, Pointier \& Guyard 1992). This paper aims to present a short review of the different freshwater snail introductions which have occurred in Martinique during the last decades and their implications in biological control programmes of the snail hosts of schistosomes.

\section{THE FRESHWATER MOLLUSCAN FAUNA OF} MARTINIQUE BEFORE THE 80'S

The freshwater malacological fauna from Martinique Island was first investigated at the end of the XIX century by Mazé (1874) and Bordaz (1899). These authors reported ten species including B. glabrata, the snail host of schistosomiasis. No malacological surveys were conducted on the island in the first half of the XXth century and later 
a first inventory was carried out by Dreyfuss (1953) who confirmed the presence of four planorbid species. At that time, B. glabrata was apparently a commonly distributed species throughout the island. In 1967, Grétillat reported six species already cited in the previous surveys and a new record for the island, B. straminea. The same year, the occurrence of this latter species was confirmed by Paraense (pers. commun.) and a malacological survey carried out between 1972 and 1978 by Guyard and Pointier (1979). In addition these authors reported for the first time the presence of another planorbid snail, Helisoma duryi (Wetherby, 1879). A total of 17 freshwater molluscs (Figs 1-2) were listed in this inventory including six planorbids $[B$. glabrata, B. straminea, B. schrammi (Crosse, 1864), Drepanotrema lucidum (Pfeiffer, 1839), D. cimex (Moricand, 1837), H. duryi], two physids [Physa cubensis Pfeiffer, 1839, P. marmorata (Guilding, 1828)], one lymnaeid (Lymnaea cubensis Pfeiffer, 1839), one ancylid [Gundlachia radiata (Guilding, 1828)], one hydrobid [Pyrgophorus coronatus (Pfeiffer, 1840)], three neritids [Neritina punctulata Lamarck, 1816, N. virginea (Linnaeus, 1758), Neritillia succinea (Recluz, 1841)], one ampullarid [Pomacea glauca (Linnaeus, 1758)] and two bivalves [Eupera viridans (Prime 1865), Pisidium punctiferum (Guppy, 1869)]. Moreover, the authors reported dense populations and a very wide distribution of $B$. straminea in the whole hydrographic system of Martinique, confirming that a successful invasion occurred several years ago. Two other species cited in the literature, Drepanotrema depressissimum (Moricand, 1839) and D. aeruginosum (Morelet, 1851) could not be collected during this survey (see in Mazé 1874, Harry \& Hubendick 1964). Thus, in 1978, two molluscs out of 17 were considered as introduced species, B. straminea and $H$. duryi (Fig. 2J, K).

The case of two other common species, $B$. glabrata and Physa cubensis, must also be emphasized. As already pointed out, B. glabrata occurred in Martinique in the XIX century and was recorded as a native species. However, this snail has a very wide distribution area extending from the Greater Antilles to south of Brazil and recently demonstrated its invasive capabilities in Egypt where it is presently colonizing the Nile delta area (Kristensen et al. 1999). Moreover, recent genetic studies revealed strong African affinities of this species suggesting a non-American origin (Bandoni et al. 1995, Woodruff \& Mulvey 1997). Its status as a native species in Martinique is thus questionable. Similarly, the origin of $P$. cubensis is also questionable. Physid snails are considered as very good travellers as a consequence of the great increase of the aquarium industry and aquatic plant trade during the last decades and these snails may colonize a great variety of anthropized habitats (Madsen \& Frandsen 1989). Moreover, their identification using morphological characters is difficult because of their shell variability and the lack of reliable anatomical studies. Consequently their taxonomic status still remains quite confusing (Brown 1994).

THE INCREASE OF ALIEN SNAIL INTRODUCTIONS IN THE 80'S AND 90'S AND BIOLOGICAL CONTROL PROGRAMMES IN MARTINIQUE

A strong increase of snail introductions was observed in Martinique during the last two decades. In 1979, the thiarid snail M. tuberculata was discovered for the first time in Madame River, Fortde-France, and in two other waterbodies in the northern part of the island (Pointier \& McCullough 1989). Conchological studies showed the presence of two distinct morphs differing in their color and sculpture patterns (Pointier 1989). The first morph named MAD (from Madame River) has a pale to dark brown shell with numerous reddish brown flames. Body whorls are slightly rounded with spiral grooves and axial undulating ribs flattening on the latter whorls (Fig. 2A). The second morph named FAL (from Falaise River) has a white shell with numerous reddish brown flames and spots. Body whorls are well rounded with spiral grooves and axial and spiral rows of tubercles (Fig. 2D).

At the beginning of 1983, a biological control experiment using $M$. tuberculata as a competitor of $B$. glabrata and B. straminea was initiated in two groups of water-cress beds which were active transmission sites for schistosomiasis in 1981 and 1982 (Pointier et al. 1984). In January 1983, $700 \mathrm{M}$. tuberculata were introduced into the first group of water-cress beds (representing a density of 1.3 individuals $/ \mathrm{m}^{2}$ ) and 700 in the second group (representing a density of 1.6 individuals $/ \mathrm{m}^{2}$ ). From November 1981 to January 1983, the period prior to the introduction of $M$. tuberculata, the water-cress beds harboured a population of $B$. glabrata varying from 45 to 256 individuals $/ \mathrm{m}^{2}$ as well as a population of $B$. straminea varying from 2 to 30 individuals $/ \mathrm{m}^{2}$ (Pointier et al. 1984). The results showed a very rapid colonization by the competitor snail, with densities reaching a maximum of 9,941 and 13,388 individuals $/ \mathrm{m}^{2}$ at 10 and 20 months respectively after its introduction into the two groups of water-cress beds. During that time, the $B$. glabrata and B. straminea populations declined and disappeared completely from samplings in 1985 (Pointier et al. 1989). Following this first success, M. tuberculata was introduced into the other groups of beds which were inventoried all over the island. The results confirmed those achieved during the 

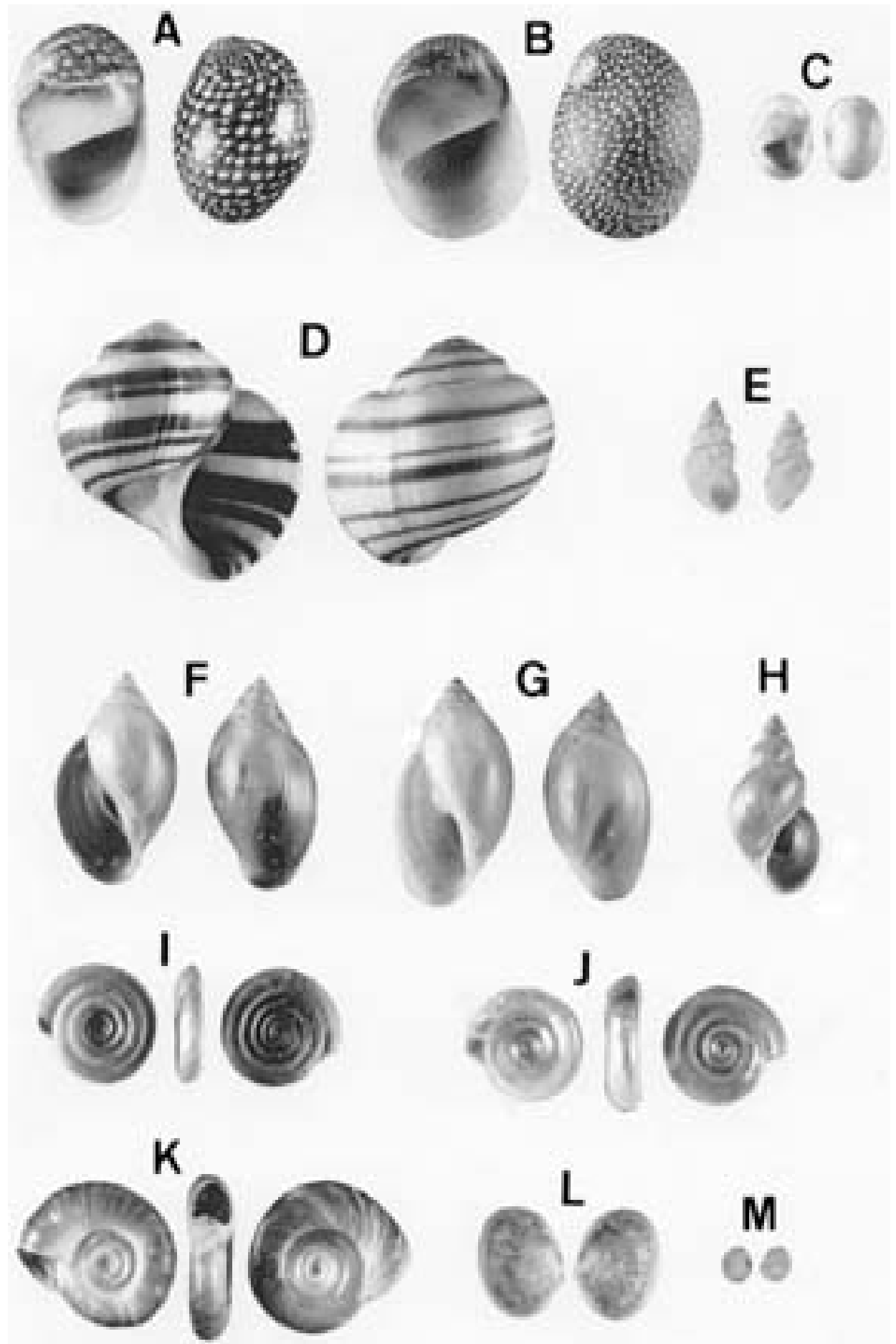

Fig. 1: freshwater malacological fauna of Martinique. Native species. A: Neritina virginea, Rivière Pilote (21.9 and 21.2 $\mathrm{mm}$ ); B: N. punctulata, Lorrain River (29.0 and $29.3 \mathrm{~mm}$ ); C: Neritillia succinea, Fond Bourlet River (5.4 and $5.2 \mathrm{~mm}$ ); D: Pomacea glauca, Saint-Pierre River $(53.2$ and $50.2 \mathrm{~mm})$; E: Pyrgophorus coronatus, Madame River (5.7 and 5.1 $\mathrm{mm})$; F: Physa cubensis, Falaise spring $(8.8$ and $8.7 \mathrm{~mm})$; G: P. marmorata, Sainte Marie canal (12.0 and $11.1 \mathrm{~mm})$; H: Lymnaea cubensis, Anse Rivière marsh $(9.2 \mathrm{~mm})$; I: Drepanotrema cimex, Boisneuf marsh (6.4, 6.0 and $6.3 \mathrm{~mm}) ; \mathrm{J}: D$. lucidum, Boisneuf marsh (6.0, 6.4 and $6.6 \mathrm{~mm})$; K: Biomphalaria glabrata, Boisneuf marsh (21.2, 22.1 and $22.6 \mathrm{~mm}$ ); L: Eupera viridans, Sainte Luce pond $(5.5 \mathrm{~mm})$; M: Pisidium punctiferum, Pelletier ravine $(2.2 \mathrm{~mm})$ 
first experiment and in 1990 B. glabrata and $B$. straminea were absent or very rare in this type of habitat (Pointier \& Guyard 1992).

Concomitantly, several malacological surveys conducted in the 1980s revealed a rapid spread of M. tuberculata all over the island. A third morph previously discovered in Guadeloupe was found in several sites in 1986. This morph named PAP (from Pointe-à-Pitre) has a pale to dark brown shell with numerous reddish brown flames. Body whorls are slightly rounded with spiral grooves. Axial ribs are present on the first whorls but disappear in the six to seven last whorls (Fig. 2B). From 1986 to 1990, a strong decline of one morph (FAL) was observed following the spread of the two others (MAD, PAP) suggesting a competitive displacement between morphs (Pointier et al. 1993).

Two pulmonate species, Gyraulus sp. and Amerianna carinata (H. Adams, 1861) as well as the ampullarid Marisa cornuarietis (Linnaeus, 1758) were also introduced in the 80's. Gyraulus sp. (Fig. 2L) was discovered in 1982 in a watercress bed near the Falaise River (unpublished data). This snail is also considered as a good traveller and is often introduced with aquatic plants used by aquarists (Madsen \& Frandsen 1989). In Martinique, it remained at the same site during several years but disappeared at the end of the 80 's following the destruction of the water-cress beds. The ampullarid M. cornuarietis (Fig. 2I) was discovered in two marshy areas located behind a mangrove forest in 1987 (Anse Rivière and Quartier Boisneuf, unpublished data). Apparently it remained restricted to these two sites in the following years. The Australian planorbid snail $A$. carinata (Fig. 2M) was discovered in 1987 in some small refuges along the banks of the Galion River (Pointier 1996). It colonized rapidly the whole island but remained restricted to particular micro-habitats sheltered from seasonal floodings along the river banks.

In the 90's, other alien snail introductions followed in Martinique. Another morph of $M$. tuberculata was discovered in Madame River, Fortde-France in 1990 and named PDC (from Pont-deChaînes). The shell is greenish to pale brown with numerous reddish brown spots and flames. Flames are well marked below sutures. Body whorls are slightly rounded with spiral grooves (Fig. 2C). This morph colonized several rivers and streams in the following years. In 1991 another thiarid species, Tarebia granifera (Fig. 2H) was discovered in the Charpentier River. It rapidly spread from its introduction site and by 1997 thirteen river systems were colonized. $T$. granifera quickly outnumbered $M$. tuberculata in rivers already colonized by this species but it never wiped it out (Pointier et al. 1998).
In 1993, a fifth morph of M. tuberculata was discovered in the Coulisses River at Petit Fond and named CPF (Fig. 2F). The shell is whitish with numerous reddish to brown spots and flames. Body whorls are slightly rounded with spiral grooves and axial undulating ribs flattening on the latter whorls. This morph displays some common conchological characters with FAL and PAP, both morphs which already occurred together in this river. A genetic analysis using DNA microsatellites as markers showed that this new morph can be interpreted as a hybrid between FAL and PAP morphs (Samadi et al. 1999). The following year, in 1994, another hybrid morph was found in the Madame River, Fortde-France and named FDF (Fig. 2E). This morph has been interpreted as a hybrid between FAL and PDC morphs (Samadi et al. 1999). Its shell is whitish to pale brown with reddish brown spots and flames. Flames and spots are well marked below sutures as in PDC shells. Body whorls are slightly rounded with spiral grooves and axial undulating ribs flattening on the latter whorls. The first hybrid morph $(\mathrm{CPF})$ is now present in three river systems whereas the second (FDF) remains restricted to the Madame River.

Finally, in 1997 another thiarid snail identified as $M$. amabilis (Reeve, 1860) was discovered in the Gondeau River. This thiarid resembles $M$. tuberculata (Fig. 2G) but its shell is whitish to dark brown with a single row of reddish brown spots below sutures more or less marked. Body whorls are flat with no spiral grooves. The first whorls have axial and spiral rows of minute tubercles disappearing rapidly on the five or six last whorls. $M$. amabilis is presently the dominant thiarid in the Gondeau River and has recently been found in three other Martinican rivers.

\section{CONSEQUENCES OF THE INVASION OF THIARIDS ON THE SNAIL HOSTS OF SCHISTOSOMES}

As already pointed out, the biological control programme undertaken in water-cress beds of Martinique can be considered to be successful because it resulted in the elimination of the snail hosts from almost half of the habitats; in the remaining sites, $B$. glabrata and $B$. straminea were at very low densities, probably without epidemiological significance for the transmission of schistosomes (Pointier \& Guyard 1992). In 1996, another malacological survey was carried out in all groups of water-cress beds and confirmed the control success of both snail hosts (Table). B. straminea was still present in half of the water-cress beds but only a few individuals could be collected in these sites colonized by $M$. tuberculata. The most striking result was the absence of $B$. glabrata from all watercress beds. When snail densities are very low, it is 


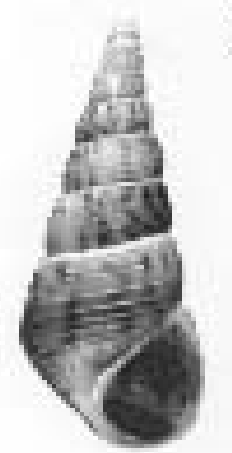

A

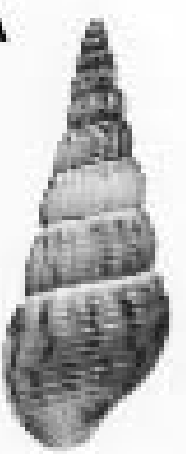

D

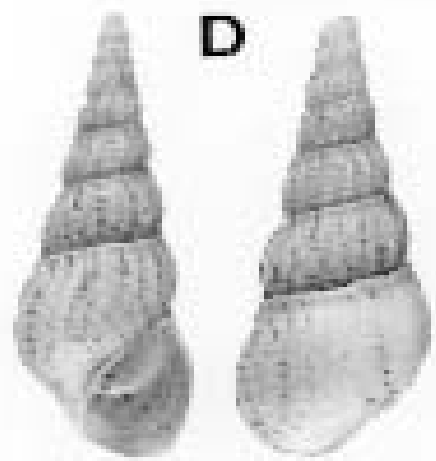

B
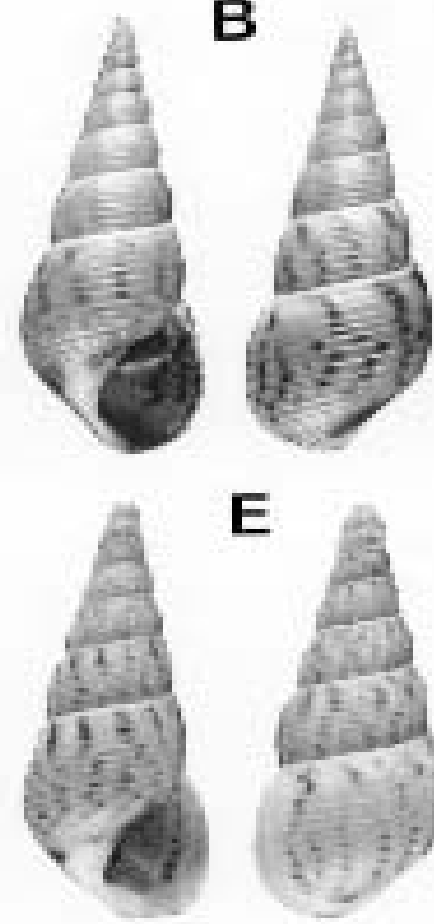

E

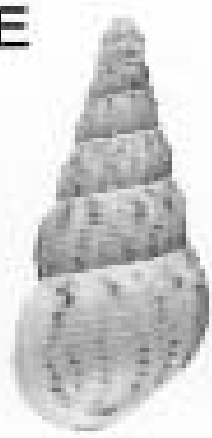

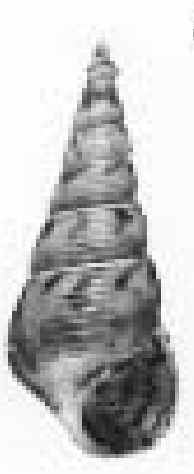

C
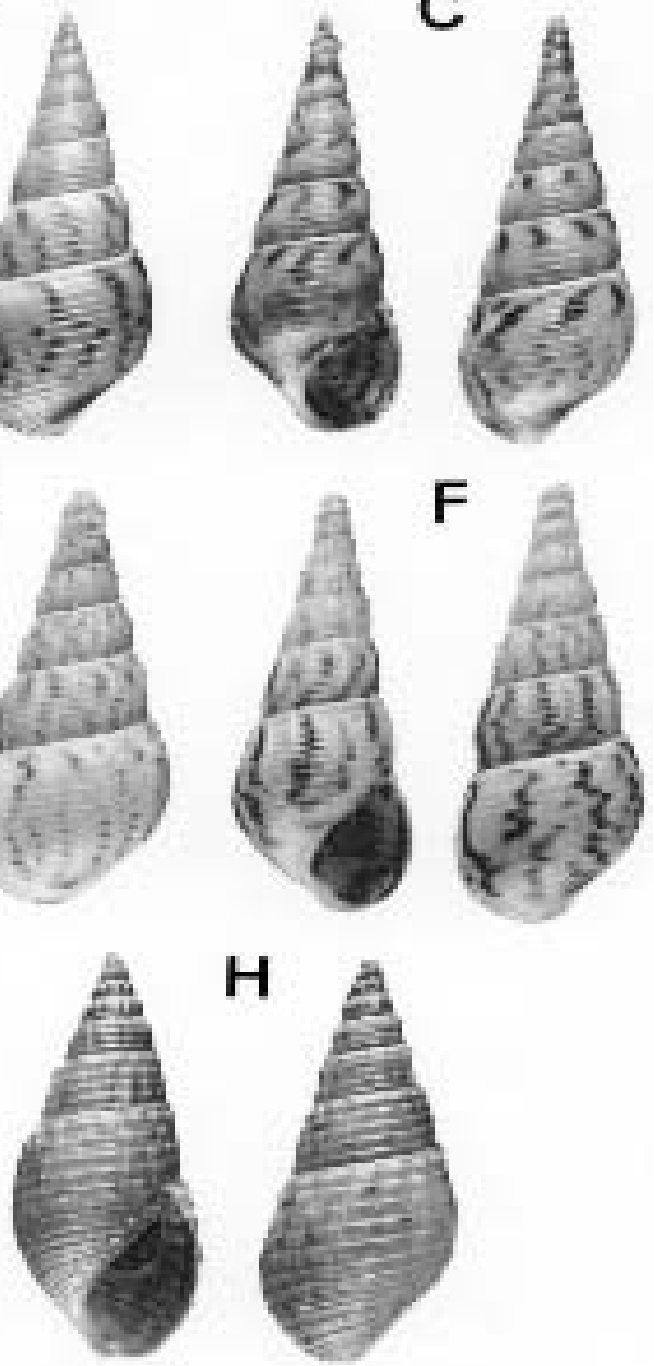

H

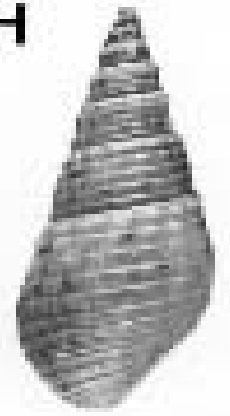

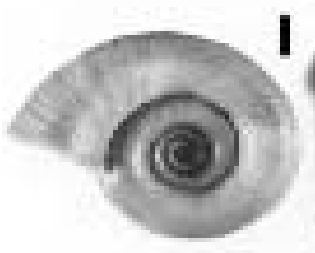
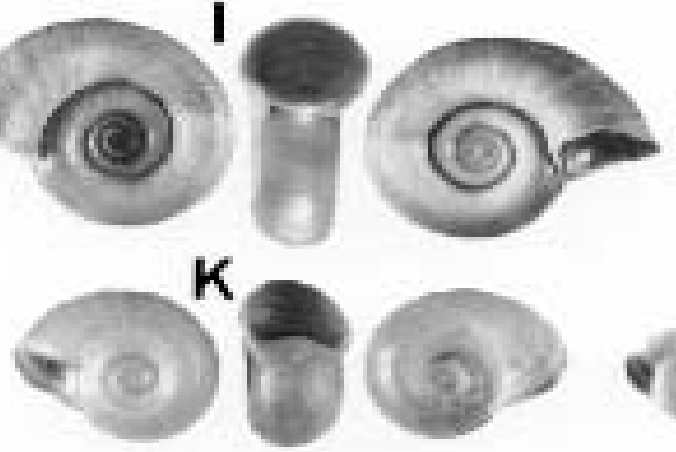

K
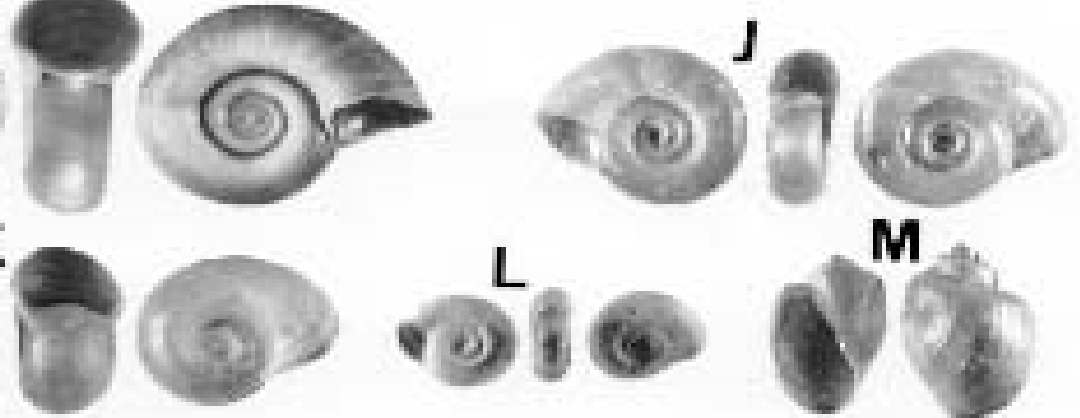

M

Fig. 2: freshwater malacological fauna of Martinique. Introduced species. A: Melanoides tuberculata, MAD morph, Madame River (24.5 and $24.7 \mathrm{~mm}$ ); B: M. tuberculata, PAP morph, Coulisses River (25.5 and $25.2 \mathrm{~mm}$ ); C: M. tuberculata, PDC morph, Coulisses River (24.2 and $25.2 \mathrm{~mm}$ ); D: M. tuberculata, FAL morph, Epinette River (26.4 and $26.8 \mathrm{~mm}$ ); E: M. tuberculata, FDF morph = FAL x PDC hybrid (25.2 and $24.5 \mathrm{~mm}) ; \mathrm{F}:$ M. tuberculata, CPF morph $=\mathrm{FAL}$ x PAP hybrid (25.3 and $26.3 \mathrm{~mm}$ ); G: M. amabilis, Gondeau River (24.0 and $22.9 \mathrm{~mm}$ ); H: Tarebia granifera, Charpentier River (23.7 and $23.8 \mathrm{~mm}$ ); I: Marisa cornuarietis, Anse Rivière marsh (53.2 mm); J: Biomphalaria straminea, Sainte Marie canal (9.0, 9.2 and $9.4 \mathrm{~mm})$; K: Helisoma duryi, Leyritz tank (15.5, 15.0 and $15.5 \mathrm{~mm})$; Gyraulus sp. Falaise watercress (3.8, 3.5 and $3.7 \mathrm{~mm})$; M: Amerianna carinata, Galion River (8.6 and $9.2 \mathrm{~mm})$ 
TABLE

Main characteristics of the water-cress beds of Martinique where a biological control programme was carried out using the competitor snail Melanoides tuberculata against Biomphalaria glabrata $(\mathrm{Bg})$ and $\mathrm{B}$. straminea $(\mathrm{Bs})$, snail intermediate hosts of schistosomiasis in the 80's

\begin{tabular}{|c|c|c|c|c|c|c|c|}
\hline Water-cress bed & Surface $\mathrm{m}^{2}$ & Type of soil & $\begin{array}{l}\text { Snail } \\
\text { hosts }\end{array}$ & $\begin{array}{l}\text { Competitor } \\
\text { introduction }\end{array}$ & $\begin{array}{c}\text { Mean density of the } \\
\text { competitor (ind. } \mathrm{m}^{2} \pm \mathrm{SD} \text { ) } \\
3 \text { years after its introduction }\end{array}$ & $\begin{array}{l}\text { State of control } \\
\quad \text { in } 1990\end{array}$ & $\begin{array}{l}\text { State of control } \\
\quad \text { in } 1996\end{array}$ \\
\hline Roxelane 1 & 530 & Mud & $B g+B s$ & Jan. 1983 & $5,900 \pm 1,050$ & Snail disappearance & Snail disappearance \\
\hline Roxelane 2 & 450 & Mud & $B g+B s$ & Jan. 1983 & $7,260 \pm 2,690$ & Snail disappearance & Some $B s$ \\
\hline Roxelane 3 & 217 & Mud + gravel & $B s$ & Jan. 1984 & $2,685 \pm 770$ & Snail disappearance & Some $B s$ \\
\hline Roxelane 4 & 138 & Mud & $B s$ & Jan. 1984 & $15,780 \pm 7,150$ & Some $B s$ & Some $B s$ \\
\hline Pointe la Mare 1 & 360 & Mud & $B g+B s$ & Nov. 1983 & $12,210 \pm 2,760$ & Some $B g+B s$ & Some $B s$ \\
\hline Pointe la Mare 2 & 165 & Mud & $B g+B s$ & Nov. 1983 & $11,270 \pm 1,730$ & Some $B g+B s$ & Some $B s$ \\
\hline Pointe la Mare 3 & 150 & Mud & $B g+B s$ & Nov. 1983 & $12,550 \pm 2,690$ & Some $B g+B s$ & Some $B s$ \\
\hline Pointe la Mare 4 & 315 & Mud & $B g+B s$ & Nov. 1983 & $11,640 \pm 1,830$ & Some $B g+B s$ & Some $B s$ \\
\hline Pointe la Mare 5 & 120 & Mud + gravel & $B g+B s$ & Nov. 1983 & $7,890 \pm 2,030$ & Some $B s$ & Some $B s$ \\
\hline Roches Carrées & 18 & Mud & $B g+B s$ & Jul. 1986 & $7,960 \pm 4,770$ & Some $B g$ & Abandon of cultures \\
\hline Haut Roches Carrées & 28 & Mud + gravel & $B g+B s$ & Unassisted & $5,840 \pm 970$ & Some $B g+B s$ & Abandon of cultures \\
\hline Rivière l'Or 1 & 48 & Gravel & $B g$ & Oct. 1984 & $1,200 \pm 450$ & Snail disappearance & Snail disappearance \\
\hline Rivière l'Or 2 & 144 & Gravel & $B s$ & Unassisted & $1,040 \pm 270$ & Snail disappearance & Snail disappearance \\
\hline Hôtel des Plaisirs & 33 & Mud & $B g$ & June 1986 & $5,560 \pm 2,650$ & Some $B g$ & Snail disappearance \\
\hline Ressource Bassignac & 40 & Mud & $B s$ & Jul. 1986 & $6,700 \pm 3,060$ & Abandon of cultures & Abandon of cultures \\
\hline Rivière Falaise & 110 & Mud + stones & $B g+B s$ & Unassisted & $9,930 \pm 1,720$ & Snail disappearance & Abandon of cultures \\
\hline Habitation Pécoul & 6 & Mud & $B s$ & Unassisted & $8,150 \pm 6,230$ & Abandon of cultures & Abandon of cultures \\
\hline Romanet 1 & 10 & Mud & $B g+B s$ & Jul. 1986 & $8,080 \pm 3,330$ & Some $B s$ & Snail disappearance \\
\hline Romanet 2 & 60 & Mud & $B g$ & Jul. 1986 & $8,530 \pm 2,960$ & Some $B g$ & Snail disappearance \\
\hline Romanet 3 & 12 & Mud & $B g$ & Jul. 1986 & $6,300 \pm 1,250$ & Snail disappearance & Snail disappearance \\
\hline Rivière des Pères & 900 & Sand + gravel & $B g+B s$ & Apr. 1986 & $2,510 \pm 510$ & Some $B g$ & Some $B s$ \\
\hline Bois de l’Union & 30 & Mud & $B s$ & Jul. 1986 & $5,480 \pm 2,310$ & Snail disappearance & Abandon of cultures \\
\hline
\end{tabular}


obviously difficult to achieve irrefutable results and it will be necessary to repeat long-term samplings in these habitats in order to have a better assessment of the malacological situation and to be sure that B. glabrata has really been eradicated from these habitats.

A last survey carried out during the dry season 2000 in the main streams and rivers of Martinique confirmed the invasion of the whole hydrographic system by thiarids. Apparently, the main consequence of this invasion is the disappearance of $B$. glabrata and the rarefaction of $B$. straminea. The impact of thiarids upon the other freshwater snail species has not been precisely studied. However, it already seems negligible on the five main prosobranch species living in running waters before the introduction of thiarids (P. glauca, N. punctulata, $N$. virginea, $N$. succinea and $P$. coronatus). Such a situation has already been observed in Guadeloupe where no changes in the malacological fauna has occurred between 1972 and 1996 in 134 sites in spite of the invasion by $M$. tuberculata (Pointier \& Augustin 1999). In Martinique the malacological inventory must be completed in other types of habitats such as ponds or marshes which are less accessible to the invasion by thiarids and which harbour several native pulmonate species.

In Martinique the invasion by thiarid snails appears as an irreversible process. Fortunately, it seems that the benefits of this invasion are more important than the disadvantages because it mainly resulted in an efficient and sustainable control of two snails responsible for the transmission of a serious disease to humans. However, in other islands or countries, this invasion may become a pest because of the impact of the invaders on endemic faunas. This may be the case for some Greater Antillean islands such as the Dominican Republic or Cuba where several endemic thiarids and pleurocerids occur.

\section{REFERENCES}

Bandoni SM, Mulvey M, Loker ES 1995. Phylogenetic analysis of eleven species of Biomphalaria Preston, 1910 (Gastropoda: Planorbidae) based on comparisons of allozymes. Biol J Linn Soc 54: 1-27.

Bordaz G 1899. Liste des coquilles recueillies à la Martinique. Bull Soc Hist Nat Autun 12: 5-24.

Brown DS 1994. Freshwater Snails of Africa and Their Medical Importance, Taylor \& Francis, London, 609 pp.

Civeyrel L, Simberloff D 1996. A tale of two snails: is the cure worse than the disease? Biodiv Conserv 5: 1231-1252.

Dreyfuss R 1953. Les planorbes de la Martinique. Bul Soc Fr Hist Nat Ant 2: 41-45.

Grétillat S 1967. Prospection malacologique aux Antilles françaises. Observations sur l'écologie et l'élevage au laboratoire de Lymnaea cubensis. Rev El Méd Vét Pays Trop 2: 279-289.

Guyard A, Pointier JP 1979. Faune malacologique dulçaquicole et vecteurs de la schistosomose intestinale en Martinique (Antilles françaises). Ann Parasitol 54: 193-205.

Harry JW, Hubendick B 1964. The freshwater pulmonate mollusca of Puerto Rico. Med Göteborgs Mus Zool Adv 136: 1-77.

Madsen H, Frandsen F 1989. The spread of freshwater snails including those of medical and veterinary importance. Acta Trop 46: 139-146.

Malek EA 1980. Snails Transmitting Parasitic Diseases, CRC Press, 134 pp.

Mazé H 1874. Catalogue des coquilles terrestres et fluviatiles recueillies à la Martinique en 1873. J Conch 22: 158-173.

Mead AR 1979. Economic malacology: with particular reference to Achatina fulica. In V Fretter, J Peake (eds), Pulmonates, Academic Press, London, p. 150.

Kristensen TK, Yousif F, Raahauge P 1999. Molecular characterization of Biomphalaria spp. in Egypt. $J$ Moll Stud 65: 133-136.

Pointier JP 1989. Comparison between two biological control trials of Biomphalaria glabrata in a pond in Guadeloupe, French West Indies. J Med Appl Mal 1: 83-95.

Pointier JP 1996. An Australian planorbid freshwater snail recently introduced to the island of Martinique: Amerianna carinata (H. Adams, 1861). Haliotis 25: 25-31.

Pointier JP 1999. Invading freshwater gastropods: some conflicting aspects for public health. Malacologia 41: 403-411.

Pointier JP, Augustin D 1999. Biological control and invading freshwater snails: a case study. CR Acad Sci Paris 322: 1093-1098.

Pointier JP, Guyard A 1992. Biological control of the snail intermediate hosts of Schistosoma mansoni in Martinique, French West Indies. Trop Med Parasitol 43: 98-101.

Pointier JP, McCullough F 1989. Biological control of the snail hosts of Schistosoma mansoni in the Caribbean area using Thiara spp. Acta Trop 46: 147-155.

Pointier JP, Guyard A, Mosser A 1989. Biological control of Biomphalaria glabrata and B. straminea by the competitor snail Thiara tuberculata in a transmission site of schistosomiasis in Martinique, French West Indies. Ann Trop Med Parasitol 83: 263-269.

Pointier JP, Guyard A, Théron A, Dumoutier A 1984. Le fonctionnement d'un site de transmission à Schistosoma mansoni en Martinique (Antilles françaises). Ann Parasitol 59: 589-595.

Pointier JP, Samadi S, Jarne P, Delay B 1998. Introduction and spread of Thiara granifera (Lamarck, 1822) into Martinique island, French West Indies. Biodiv Conserv 7: 1277-1290.

Pointier JP, Thaler L, Delay B, Pernot F 1993. Invasion of the Martinique island by the parthenogenetic snail Melanoides tuberculata and succession of morphs. Acta Oecol Int J Ecol 14: 33-42.

Pointier JP, Théron A, Imbert-Establet D, Borel G 1991. 
Eradication of a sylvatic focus of Schistosoma mansoni using biological control by competitor snails. Biol Contr 1: 244-247.

Prentice MA 1983. Displacement of Biomphalaria glabrata by the snail Thiara granifera in field habitats in St Lucia, West Indies. Ann Trop Med Parasitol 77: 51-59.

Samadi S, Mavárez J, Pointier JP, Delay B, Jarne P 1999. Microsatellite and morphological analysis of popu- lation structure in the parthenogenetic freshwater snail Melanoides tuberculata: insights into the creation of clonal variability. Mol Ecol 8: 1141-1153.

Williamson M 1996. Biological Invasions, Chapman \& Hall, 244 pp.

Woodruff DS, Mulvey M 1997. Neotropical schistosomiasis: African affinities of the host snail Biomphalaria glabrata (Gastropoda: Planorbidae). Biol J Linn Soc 60: 505-516. 